Sahin $\mathrm{S}^{* 1}$, Ozdemir $\mathrm{K}^{*}$, Unsal $\mathrm{A}^{* * 2}$

\title{
EVALUATION OF THE RELATIONSHIP BETWEEN INTERNET ADDICTION AND DEPRESSION IN UNIVERSITY STUDENTS
}

Objective: To assess the Internet addiction and depression level in university students.

Methods: The present study is a cross-sectional study conducted on the students of Sakarya University between 05 April and 05 July 2012. After the departments were selected by casting lots, 994 students who were randomly selected from each class constituted the study group. Students in the classrooms were informed about the objective and purpose of the study. Then they were asked to complete the previously prepared questionnaire under supervision. In the current study, the Internet Addiction Scale was used in order to assess the Internet addiction. The higher scores obtained in the scale represent higher level of Internet addiction. Depression was assessed with the Beck Depression Inventory. Students with a score of 17 and above were regarded to have suspected depression. Data were assessed in SPSS (version 15.0) Statistics Package Program on the computer. Student's t-test, One-Way Analysis of Variance and Spearman's Correlation Analysis were used for analyses. Statistical significance value was taken as $\mathrm{p}<0.05$.

Results: The study group consisted of 573 (57.6\%) females and 421 $(42.4 \%)$ males. They were aged between 18 and 26 with a mean age of $21.10 \pm 1.71$ years. The scores obtained by the students from the Internet Addiction Scale ranged between 0-90 with a mean score of $20.04 \pm 12.85$. The scores obtained from the Beck Depression Inventory ranged between 0 -53 with a mean score of $11.32 \pm 9.23$. In our study, frequency of suspected depression was determined to be $23.0 \%(n=229)$. In the present study, Internet addiction level was determined to be higher in males,

\footnotetext{
Sakarya University School of Health

** Eskişehir Osmangazi University
} 
those with high family income, those staying in dormitory, smokers, those with an extroverted personality, those having Internet access, those using Internet once a day or more and students with suspected depression $(\mathrm{p}<0.05$ for each).

Discussion: Internet addiction is an important health problem in university students. A significant relationship was determined between Internet addiction and depression.

Key words: University students, Internet addiction, depression, Turkey

\section{INTRODUCTION}

As a global communication system of interconnected computer networks, Internet is a technology created based on the ever-increasing desire to "store, share and easily access the generated information". ${ }^{1}$ On December $2011,32.7 \%$ of all people around the world and $44.4 \%$ of the Turkish population use the Internet (http://www. internetworldstats.com/stats.htm Access date: 11/10/2012).

Internet addiction can be broadly defined as irrepressible desire to overuse Internet, the perception that time spent without Internet connection is futile, hyperirritability and aggression in case of deprivation, and progressive disruption of business, social and family life of a person. ${ }^{2,3}$

Internet use is more common in young population as they are more interested in technology. ${ }^{4,5}$ It is known that the young people use the Internet for reasons such as research, homework, socializing, downloading music and films, gaming, pornography etc. ${ }^{6,7}$

It is a well-known fact that young people who spend a significant amount of time by using computer have important issues in interpersonal relationships. It was reported that the young people and children using the Internet in extended periods become gradually isolated and have difficulties in face-to-face communication. . $^{8,9,10}$

Some studies indicate that people develop a new life style based on their Internet activities and negative consequences may occur in real social relations. In other words, depressive individuals rely on the Internet for social assistance, which increases the risk of developing internet addiction as a result of the deterioration of interpersonal relations in their real life. ${ }^{9,11}$

The concept of depression may be regarded as both a cause and an effect for the Internet addiction. An individual who suffers from depression because of other sociological or psychological factors may either turn towards the Internet and become addicted or become depressed because of the addiction after developing addiction. ${ }^{12}$

This study was conducted to assess the relationship between the Internet addiction and depression in the students of Sakarya University. 


\section{MATERIAL AND METHOD}

This cross-sectional study was conducted on the students of Sakarya University between 05 April and 05 July 2012.

The number of students at this university in 2011-2012 Academic Year was 31,668. Sample size for this study was calculated as 841 students (incidence of the condition is $11.0 \%$, margin of error 0.04 , confidence level $95.0 \%$ ). After the departments were selected by casting lots, 994 students who were randomly selected from each class constituted the study group.

The questionnaire prepared based on the literature ${ }^{9,13,14,15}$ included questions on some socio-demographic characteristics, some factors believed to be associated with the Internet addiction, Young's Internet Addiction Test and Beck Depression Inventory.

After required approvals had been obtained from the university management, students were gathered in classes and informed about the subject and objective of the study. Informed verbal consents were obtained from those who agreed to take part in the study. Previously prepared questionnaires were completed by the students under supervision. This procedure lasted for 20-25 minutes. The study group consisted of 994 students who were present at the school and agreed to take part in the study. The rules stated in the Helsinki Declaration were complied in the stage of data collection.

Young's Internet Addiction Scale used for assessing Internet addiction was developed by Young in 1998 (Young, 1998), whose reliability and safety study in Turkey was conducted by Bayraktar in $2001 .{ }^{16}$ The scores to be obtained from the 20 -item scale with 6 Likert type items ranged between 0 and 100. The higher scores denote to increased addiction level. The score of 50 and above was deemed to "have Internet addiction".

Beck Depression Inventory (BDI) used for assessing depression is one of the most widely used scales for depression screening in adults and was developed by Beck et al. in 1961. Turkish reliability and validity study was conducted by Hisli in 1999..$^{17,18}$ The inventory consists of 21 questions with four answer choices. A value of 0 to 3 was assigned to each answer with a total score of 0 to 63 . Individuals who obtained a score of 17 and above from this inventory were regarded to have "suspected depression".

In our study, family income level was assessed as high, medium and poor by the students. The students smoking at least one cigarette a day were considered "smokers". ${ }^{19}$

Those who defined themselves as uptight, enthusiastic, hasty and impatient were classified as "extroverted personality" and those who defined themselves as quiet, calm, patient and organized were classified as "introverted personality". ${ }^{20}$ The students whose parents are actively engaged with a revenue-generating business were defined as "employed".

After completing the questionnaire, weight and height of the students were measured to calculate the Body Mass Index (BMI). Those with a BMI equal to or above $25 \mathrm{~kg} / \mathrm{m}^{2}$ were considered as overweight/obese. ${ }^{21}$ 
The data was evaluated in IBM SPSS (version 20.0) Statistical Package Program. Mann-Whitney U test (z), Kruskal-Wallis test (KW) and Spearman's Correlation Analysis $\left(\mathrm{r}_{\mathrm{s}}\right)$ were used for the analyses. Statistical significance value was accepted as $\mathrm{p}<0.05$.

\section{RESULTS}

573 students (57.6\%) were female and $421(42.4 \%)$ were male. Mean age was $21.10 \pm 1.71$ years (min: 18 , max: 26 ). The scores obtained from the Internet addiction scale ranged between 0 and 90 with a mean of $20.04 \pm 12.85$ points. The frequency of Internet addiction was determined to be $8.4 \%(n=83)$. The distribution of the scores obtained by the students from Internet addiction scale by some socio-demographic characteristics is given in the Table 1.

481 students had Type A personality. In the study, smoking frequency was $21.0 \%$, number of overweight/obese students was 155 , number of physically handicapped ones was 47 and those with a chronic disease was 96 . Frequency of suspected depression was determined to be $23.0 \%(\mathrm{n}=229)$. The distribution of the scores obtained by the students in the study group from the Internet addiction scale by some diseases and other characteristics is given in the Table 2.

The mothers of 108 and fathers of 49 students were not literate. 142 students had working mothers and 612 students had working fathers. 32 students had no siblings whereas 414 students were the first-born child in the family. The distribution of the scores obtained by the students from Internet addiction scale by some characteristics of the parents is given in the Table 3 .

The top reason of using the Internet by the students was studying $(21.4 \%)$ and the least one was loneliness (4.1\%). The reasons for using the Internet by the participants in the study group are given in the Table 4.

The mean age for first Internet use was $13.50 \pm 2.63$ years (min: 6; max: 21) in our study. 791 students stated to have Internet access and there were 718 students using the Internet at least once a day and 181 students using 4 hours or more in a day. The average duration of daily use was $2.38 \pm 1.96$ hours (min: 0 ; max: 20 ). Their academic grade point average was $2.42 \pm 0.53$ (min: 1.0 ; max: 4.0 ). The distribution of the scores obtained by the students from the Internet addiction scale by some characteristics of the Internet use and academic grade point average is given in the Table 5.

The average score obtained by the students from the Beck Depression Inventory was $11.32 \pm 9.23$ (min: 0; $\max : 53$ ). There was a positive relationship between the scores obtained from the Internet addiction scale and Beck Depression Inventory $\left(\mathrm{r}_{\mathrm{s}}=0.299\right.$; $\mathrm{p}=0.000$ ). The distribution of the scores obtained from the Internet addiction scale and Beck Depression Inventory is given in the Figure 1. 
Table 1. The distribution of the scores obtained by the students in the study group from the Internet addiction scale by some socio-demographic characteristics

\begin{tabular}{|c|c|c|c|c|c|}
\hline $\begin{array}{l}\text { Socio-demographic } \\
\text { characteristics }\end{array}$ & n & $\begin{array}{l}\text { Score of Internet } \\
\text { Addiction Scale } \\
\text { Median (min-max) }\end{array}$ & $\begin{array}{l}\text { Test value } \\
\text { z/KW; p }\end{array}$ & $\begin{array}{l}\text { Multiple } \\
\text { comparison }\end{array}$ & $\mathrm{p}$ \\
\hline \multicolumn{6}{|l|}{ Faculty name } \\
\hline Business Administration & 113 & $21.0(5.0-46.0)$ & \multirow{8}{*}{$67.477 ; 0.000$} & $6-5$ & 0.011 \\
\hline $\begin{array}{l}\text { Economics and Admin. Sciences } \\
\text { (2) }\end{array}$ & 144 & $19.0(0.0-65.0)$ & & $6-2$ & 0.010 \\
\hline Engineering & 140 & $24.0(5.0-73.0)$ & & $6-1$ & 0.000 \\
\hline School of Health (4) & 140 & $16.0(0.0-74.0)$ & & $6-3$ & 0.000 \\
\hline $\begin{array}{l}\text { School of Physical Edu. and Sports } \\
\text { (5) }\end{array}$ & 179 & $17.0(2.0-66.0)$ & & $4-1$ & 0.038 \\
\hline Arts and Sciences (6) & 278 & $14.0(0.0-90.0)$ & & $4-3$ & 0.000 \\
\hline- & - & - & & $5-3$ & 0.001 \\
\hline- & - & - & & $2-3$ & 0.004 \\
\hline \multicolumn{6}{|l|}{ Sex } \\
\hline Female & 573 & $15.0(0.0-74.0)$ & \multirow[b]{2}{*}{$6.032 ; 0.000$} & \multirow[b]{2}{*}{ - } & \multirow[b]{2}{*}{ - } \\
\hline Male & 425 & $20.0(0.0-90.0)$ & & & \\
\hline \multicolumn{6}{|l|}{ Age group } \\
\hline$\leq 19$ & 180 & $17.0(1.0-62.0)$ & \multirow{5}{*}{$5.470 ; 0.242$} & - & - \\
\hline 20 & 210 & $20.0(0.0-90.0)$ & & - & - \\
\hline 21 & 226 & $19.0(0.0-73.0)$ & & - & - \\
\hline 22 & 167 & $17.0(0.0-74.0)$ & & - & - \\
\hline$\geq 23$ & 211 & $16.0(0.0-66.0)$ & & - & - \\
\hline \multicolumn{6}{|l|}{ Family type } \\
\hline Nuclear & 841 & $17.0(0.0-74.0)$ & \multirow{3}{*}{$0.540 ; 0.763$} & - & - \\
\hline Extended & 111 & $19.0(2.0-73.0)$ & & - & - \\
\hline Divorced & 42 & $19.5(0.0-90.0)$ & & - & - \\
\hline \multicolumn{6}{|l|}{ Family income } \\
\hline Poor & 39 & $19.0(0.0-90.0)$ & \multirow{3}{*}{$3.634 ; 0.162$} & - & - \\
\hline Moderate & 662 & $17.0(0.0-74.0)$ & & - & - \\
\hline Good & 293 & $19.0(0.0-73.0)$ & & - & - \\
\hline \multicolumn{6}{|l|}{ Where they stay } \\
\hline With family (1) & 210 & $14.0(0.0-90.0)$ & \multirow{6}{*}{$22.778 ; 0.000$} & $1-2$ & 0.069 \\
\hline Home $\quad(2)$ & 376 & $17.0(0.0-74.0)$ & & $1-3$ & 0.000 \\
\hline Dormitory (3) & 373 & $20.0(0.0-73.0)$ & & $1-4$ & 0.120 \\
\hline Apart (4) & 35 & $21.0(3.0-56.0)$ & & $2-3$ & 0.080 \\
\hline- & - & - & & $2-4$ & 1.000 \\
\hline- & - & - & & $3-4$ & 1.000 \\
\hline Total & 994 & $18.0(0.0-90.0)$ & - & - & - \\
\hline
\end{tabular}


Table 2. The distribution of the scores obtained by the students in the study group from the Internet addiction scale by some diseases and other characteristics

\begin{tabular}{|c|c|c|c|}
\hline Diseases/habits & $\mathrm{n}$ & $\begin{array}{c}\text { Score of Internet Addiction Scale } \\
\text { Median (min-max) }\end{array}$ & $\begin{array}{l}\text { Test value } \\
\mathrm{z}: \mathrm{p}\end{array}$ \\
\hline \multicolumn{4}{|l|}{ Personality type } \\
\hline Extroverted & 481 & $19.0(0.0-66.0)$ & \multirow[b]{2}{*}{$3.231 ; 0.001$} \\
\hline Introverted & 513 & $17.0(0.0-90.0)$ & \\
\hline \multicolumn{4}{|l|}{ Smoking } \\
\hline Non-smoker & 785 & $17.0(0.0-74.0)$ & \multirow[b]{2}{*}{$3.632 ; 0.000$} \\
\hline Smoker & 209 & $20.0(0.0-90.0)$ & \\
\hline \multicolumn{4}{|c|}{ Overweight/obese } \\
\hline No & 839 & $17.0(0.0-74.0)$ & \multirow[b]{2}{*}{$1.630 ; 0.103$} \\
\hline Yes & 155 & $20.0(1.0-90.0)$ & \\
\hline \multicolumn{4}{|c|}{ Physically handicapped } \\
\hline No & 947 & $17.0(0.0-90.0)$ & \multirow[b]{2}{*}{$1.767 ; 0.077$} \\
\hline Yes & 47 & $25.0(3.0-57.0)$ & \\
\hline \multicolumn{4}{|c|}{ Story of a physician-diagnosed chronic disease } \\
\hline No & 898 & $18.0(0.0-74.0)$ & \multirow[b]{2}{*}{$0.209 ; 0.834$} \\
\hline Yes & 96 & $17.0(1.0-90.0)$ & \\
\hline \multicolumn{4}{|l|}{ Depression } \\
\hline No & 765 & $16.0(0.0-65.0)$ & \multirow{3}{*}{$8.628 ; 0.000$} \\
\hline Yes & 229 & $24.0(0.0-90.0)$ & \\
\hline Total & 994 & $18.0(0.0-90.0)$ & \\
\hline
\end{tabular}


Table 3. The distribution of the scores obtained by the students in the study group from the Internet addiction scale by some characteristics of the parents

\begin{tabular}{|c|c|c|c|}
\hline Some characteristics & $\mathrm{n}$ & $\begin{array}{c}\text { Score of Internet Addiction Scale } \\
\text { Median (min-max) }\end{array}$ & $\begin{array}{l}\text { Test value } \\
\text { z/KW; } p\end{array}$ \\
\hline \multicolumn{4}{|c|}{ Education status of mother } \\
\hline Below primary school & 108 & $15.0(2.0-61.0)$ & \multirow{5}{*}{$6.422 ; 0.170$} \\
\hline Primary school & 495 & $18.0(0.0-74.0)$ & \\
\hline Secondary school & 144 & $18.0(0.0-55.0)$ & \\
\hline High school & 158 & $21.0(0.0-65.0)$ & \\
\hline University & 89 & $17.0(0.0-90.0)$ & \\
\hline \multicolumn{4}{|c|}{ Education status of father } \\
\hline Below primary school & 49 & $15.0(2.0-46.0)$ & \multirow{5}{*}{$1.365 ; 0.850$} \\
\hline Primary school & 303 & $17.0(0.0-74.0)$ & \\
\hline Secondary school & 178 & $19.0(0.0-62.0)$ & \\
\hline High school & 261 & $18.0(0.0-65.0)$ & \\
\hline University & 203 & $18.0(1.0-90.0)$ & \\
\hline \multicolumn{4}{|c|}{ Employment status of mother } \\
\hline Unemployed & 852 & $18.0(0.0-74.0)$ & \multirow[t]{2}{*}{$1.419 ; 0.156$} \\
\hline Employed & 142 & $16.0(0.0-90.0)$ & \\
\hline \multicolumn{4}{|c|}{ Employment status of father } \\
\hline Unemployed & 382 & $17.0(0.0-90.0)$ & \multirow[t]{2}{*}{$0.756 ; 0.450$} \\
\hline Employed & 612 & $18.0(0.0-73.0)$ & \\
\hline \multicolumn{4}{|l|}{ Number of siblings } \\
\hline 0 & 32 & $17.5(0.0-42.0)$ & \multirow{4}{*}{$5.828 ; 0.120$} \\
\hline 1 & 234 & $20.0(0.0-90.0)$ & \\
\hline 2 & 318 & $18.0(1.0-62.0)$ & \\
\hline 3 and above & 410 & $17.0(0.0-74.0)$ & \\
\hline \multicolumn{4}{|c|}{ Birth order of the student } \\
\hline $1^{\text {st }}$ & 414 & $18.0(0.0-90.0)$ & \multirow{5}{*}{$2.287 ; 0.515$} \\
\hline $2^{\text {nd }}$ & 320 & $19.0(0.0-65.0)$ & \\
\hline $3^{\text {rd }}$ & 125 & $16.0(0.0-65.0)$ & \\
\hline $4^{\text {th }}$ and above & 135 & $18.0(0.0-60.0)$ & \\
\hline Total & 994 & $18.0(0.0-90.0)$ & \\
\hline
\end{tabular}


Table 4. Reasons of using the Internet by the students in the study group

\begin{tabular}{|l|c|c|}
\hline \multicolumn{1}{|c|}{ Reasons of using the Internet } & Number & Percentage \\
\hline Searching & 625 & 21.4 \\
\hline Social networking & 570 & 19.5 \\
\hline Loneliness & 119 & 4.1 \\
\hline Gaming & 321 & 10.9 \\
\hline Watching movie & 453 & 15.5 \\
\hline Listening music & 442 & 15.1 \\
\hline Watching news & 395 & 13.5 \\
\hline Total & 2925 & 100.0 \\
\hline
\end{tabular}

Table 5. The distribution of the scores obtained by the students in the study group from the Internet addiction scale by some characteristics of the Internet use and academic grade point average

\begin{tabular}{|c|c|c|c|c|c|}
\hline Some characteristics & $\mathrm{n}$ & $\begin{array}{l}\text { Score of Internet Addiction Scale } \\
\text { Median (min-max) }\end{array}$ & $\begin{array}{l}\text { Test value } \\
\text { z/KW; }\end{array}$ & $\begin{array}{l}\text { Multiple } \\
\text { comparison }\end{array}$ & $\mathrm{p}$ \\
\hline \multicolumn{6}{|l|}{ Age of first Internet use } \\
\hline$\leq 11 \quad(1)$ & 188 & $22.0(0.0-90.0)$ & \multirow{4}{*}{$31.198 ; 0.000$} & $1-3$ & 0.000 \\
\hline $12-13(2)$ & 276 & $19.0(0.0-58.0)$ & & $1-4$ & 0.000 \\
\hline $14-15(3)$ & 341 & $15.0(0.0-74.0)$ & & $2-3$ & 0.005 \\
\hline$\geq 16 \quad(4)$ & 189 & $15.0(0.0-62.0)$ & & $2-4$ & 0.019 \\
\hline \multicolumn{6}{|c|}{ Internet access where they stay } \\
\hline Not available & 203 & $13.0(0.0-62.0)$ & \multirow[b]{2}{*}{$4.686 ; 0.000$} & \multirow[b]{2}{*}{-} & \multirow[b]{2}{*}{-} \\
\hline Available & 791 & $19.0(0.0-90.0)$ & & & \\
\hline \multicolumn{6}{|l|}{ Frequency of Internet use } \\
\hline At least once a day (1) & 718 & $20.0(0.0-90.0)$ & \multirow{3}{*}{$88.522 ; 0.00$} & $1-2$ & 0.000 \\
\hline At least once a week (2) & 181 & $11.0(0.0-62.0)$ & & $1-3$ & 0.000 \\
\hline At least once a month (3) & 95 & $11.080 .0-58.0)$ & & $2-3$ & 0.271 \\
\hline \multicolumn{6}{|c|}{ Duration of daily Internet use (hour) } \\
\hline$\leq 1(1)$ & 367 & $12.0(0.0-62.0)$ & \multirow{6}{*}{$184.840 ; 0.000$} & $1-2$ & 0.000 \\
\hline $2(2)$ & 307 & $17.0(1.0-74.0)$ & & $1-3$ & 0.000 \\
\hline $3(3)$ & 139 & $21.0(0.0-73.0)$ & & $1-4$ & 0.000 \\
\hline$\geq 4(4)$ & 181 & $27.0(2.0-90.0)$ & & $2-3$ & 0.005 \\
\hline- & - & - & & $2-4$ & 0.000 \\
\hline- & - & - & & $3-4$ & 0.006 \\
\hline \multicolumn{6}{|c|}{ Academic grade point average } \\
\hline$\leq 1.89 \quad(1)$ & 131 & $21.0(0.0-62.0)$ & \multirow{3}{*}{$7.802 ; 0.020$} & $3-2$ & 0.023 \\
\hline $1.90-2.95(2)$ & 684 & $18.0(0.0-74.0)$ & & $3-1$ & 0.080 \\
\hline$\geq 2.96 \quad(3)$ & 179 & $15.0(0.0-90.0)$ & & $2-1$ & 1.000 \\
\hline Total & 994 & $18.0(0.0-90.0)$ & - & - & - \\
\hline
\end{tabular}


Figure 1. The distribution of the scores obtained by the students from the Internet addiction scale and Beck Depression Inventory

Score of Beck Depression Inventory

Score of Internet addiction scale

\section{Discussion}

Internet use has been on the increase in our country as well as all around the world. Internet addiction is an important health problem more frequently observed in the adolescence as adolescents are more vulnerable both socially and emotionally. In our study, frequency of the Internet addiction was determined to be $8.4 \%$. Fairly different results have been reported in the studies conducted on the Internet addiction in the youth. ${ }^{11,13,22,23}$ The reasons of different results may include the use of different methods to diagnose the Internet addiction, conduct of the studies on different populations in different countries and dissimilarity of research methods.

Due to different cultural values in various communities, lack of sufficient control among men on reading news, chat, gaming and gambling, virtual sex and meeting with new people has been associated with more frequent incidence of Internet addiction in men. Internet addiction level was found to be higher in the male students in our study $(p<0.05)$. Similar results have been reported in some studies. ${ }^{6,8,24,25}$

Family income is one of the indirect indicators of the socio-economic status. It is a well-known fact that the higher socio-economic status is associated with higher Internet addiction in children. ${ }^{26}$ However, our study found no relationship between the family income and Internet addiction level $(p>0.05)$. Studies reporting similar results are available. ${ }^{26,27}$ While the cost of Internet was higher and Internet access was more difficult in the early years of Internet, it is possible that the relationship between addiction and socio-economic status may have weakened along with the lower prices of Internet use and easier access.

As it is easier to access Internet from locations such as home or dormitory, it is possible for the people staying at such places to be addicted at a higher level. ${ }^{26,27} \mathrm{In}$ our study, Internet addiction level was determined to be higher in the students staying at dormitories $(\mathrm{p}<0.05)$. It might have resulted from staying alone or with friends rather than with the family which is one of the restricting factors for the Internet use. A similar result was obtained in the study of Canan et al. ${ }^{23}$

As for the relationship between the Internet addiction and personality type, some investigators stated that the Internet addiction is more frequently observed in shy and introverted individuals whereas other investigators reported that it is more frequent in extroverted ones. In this study, the Internet addiction level was found to be higher 
in those with an extroverted personality $(\mathrm{p}<0.05)$. Similar results were reported in a study of Morahan-Martin. ${ }^{10}$ It is stated that extroverted individuals are in need of more communication compared to introverted individuals, which is why they mostly use the Internet for communication. The study of Batigun and Kilic determined no relationship with the Internet addiction in extroverted individuals. ${ }^{9}$

The Internet addiction level was found to be higher in the smokers in the study group $(\mathrm{p}<0.05)$. Although there are investigators who reported that the addiction level is higher in the smokers, ${ }^{22,28}$ some investigators stated that there is no connection between the Internet addiction and smoking. ${ }^{29,30}$ This result indicates that more detailed studies are needed in order to establish the relationship between smoking and the Internet addiction.

Depression is believed to be important in the development of Internet addiction. ${ }^{16,31}$ In the present study, Internet addiction level was higher in the students with depression $(p<0.05)$. There are several investigators reporting similar results. . $^{32,33,34}$

The easier access to the Internet by the students whose parents are highly educated and employed and no restriction on their Internet use may increase the Internet addiction risk in the students. No difference was found between the Internet addiction level and education status of the parents, employment, number of siblings and birth order of the student in our study ( $p>0.05$ for each). Although addiction level was higher in the students having Internet access where they stay, interestingly, there was no difference between the addiction and some characteristics of the parents.

It is known that some interactive functions in the Internet are more addictive as they provide means for social assistance, change of identity and sexual arousal. ${ }^{26}$ In our study, while the top reasons for using the Internet included studying and social networking, the least influential reasons were loneliness and gaming. Although there are several investigators reporting similar results ${ }^{35,36}$ there are investigators stating that the Internet use for entertainment purposes is more common. ${ }^{22,37}$ The reasons of different results reported may include the conduct of the studies on different populations and different age groups in different cultures.

Unlike the addiction of psychoactive drugs, alcohol and gambling, the Internet addiction is known to have an earlier onset. ${ }^{38}$ Starting to use the Internet in early ages is a risk factor for the Internet addiction. In our study, the Internet addiction was found to be higher in the individuals who started to use the Internet in early ages $(\mathrm{p}<0.05)$. The reasons of higher Internet addiction in children who started to use the Internet in early ages may include facts that Internet has always been in their lives and taken an important place.

In this study, the Internet addiction level was determined to be higher in those using the Internet at least once a day $(\mathrm{p}<0.05)$. The higher Internet addiction was reported in those using the Internet more frequently by some studies. ${ }^{14,33}$

It is a known fact that there is a positive relationship between the duration of Internet use and Internet addiction. The use of Internet for 40 to 80 hours in a week or 
for a single session up to 20 hours is an hospitalization criterion for the addiction. The higher duration of daily Internet use in our study denoted to higher Internet addiction levels $(\mathrm{p}<0.05)$. There are studies reported similar results. ${ }^{7,39}$

As with other addictions, the addicts of Internet face problems in many aspects of life. These problems may include failure in academic life. ${ }^{31}$ Some investigators reported that academic success is adversely affected from the Internet addiction. ${ }^{40,41,42}$ Kubey et al. reported that the Internet addiction has negative impacts on academic success as it causes staying up late, fatigue and missing classes. ${ }^{40}$ In our study, the higher Internet addiction levels were determined in the students with lower academic grade point average in line with the literature $(p<0.05)$.

Depression may be both cause and effect for the Internet addiction. Those who suffer from depression because of other sociological or psychological factors may either turn towards the Internet and become addicted or become depressed because of the addiction after developing addiction. ${ }^{43}$ It is also possible that addicts may be depressed when they do not use the Internet. In our study a positive relationship was found between the Internet addiction and depression in the students $(p<0.05)$. Similar results have been reported in several studies..$^{35,44,45}$ The studies of Niemz et al. and Sanders et al. reported no relationship between the Internet addiction and depression level. ${ }^{46,47}$

\section{Limitations}

The limitations of the study may include the facts that the study was cross-sectional, it was conducted at a single university and the scales used for diagnosis of Internet addiction and depression fail to provide a definitive diagnosis.

\section{Conclusion and suggestions}

The Internet addiction is an important medical and social problem in the university students. There was a positive relationship between the Internet addiction and depression levels. It would be advantageous to refer the students with diagnosed and suspected addiction and depression to the specialists for definitive diagnosis and treatment, to make occasional scans for early diagnosis and to inform the students on the responsible use of the Internet. More comprehensive studies are required to establish the relationship between the Internet addiction and depression.

\section{Acknowledgments}

The authors wish to thank all the university students who joined this study that was performed there. 


\section{Conflict of Interests:}

The authors declare that they have no conflicting interests and the article is completed.

\section{Authors' Contributions:}

Study concept and design: Sahin S, Ozdemir K, Unsal A

Acquisition of subjects and data: Sahin S, Ozdemir K,

Analysis and interpretation of data: Unsal A, Sahin S, Ozdemir K

Preparation of manuscript: Sahin S, Ozdemir K, Unsal A,

All authors have read and approved the final version of the manuscript.

\section{References}

Tarı Cömert I, Kayıran SM. Çocuk ve Ergenlerde İnternet Kullanımı. Çocuk Dergisi 2010; 10(4):166-170.

Young KS. Internet Addiction: the Emergence of a New Clinical Disorder. Paper Presented at the 104th Annual Convention of the American Psychological Association, Toronto, Canada, 1996.

Arısoy Ö. Internet Addiction and Its Treatment. Current Approaches in Psychiatry 2009; 1(1): $55-67$.

Treuer T, Fabian Z, Furedi, J. Internet Addiction Associated with Features of Impulse Control Disorder: Is it a Real Psychiatric Disorder? J Affect Disorders 2001; 66(2-3), 283.

Widyanto L, Marymcmurran M. The Psychometric Properties of the Internet Addiction Test. Cyberpsychol Behav 2004; 7 (4), 443-450.

Morahan- Martin JM, Schumacher P. Incidents and Correlates of Pathological Internet Use among College Students. Cumput Human Behav 2000; 2:425-430.

Simkova B, Cincera J. Internet Addiction Disorder and Chatting in the Czech Republic, Cyberpsychol Behav 2004; 7 (5), 536-539.

Kelleci M. İnternet, Cep Telefonu, Bilgisayar Oyunlarının Çocuk ve Gençlerin Ruh Sağlığına Etkisi. TAF Preventive Medicine Bulletin 2008; 7(3): 253-256.

Batıgün DA, Kılıç N. İnternet Bağımlılığı ile Kişilik Özellikleri, Sosyal Destek, Psikolojik Belirtileri ve Bazı Sosyo-Demografik Değiş̧kenler Arasındaki İlişkiler. Türk Psikoloji Dergisi 2011; 26(67):1-10.

Morahan-Martin JM. The Relationship between Loneliness and Internet Use and Abuse. Cyberpsychol Behav 1999; 2: 431-439.

Yen JY, Ko CH, Yen CF, Chen CS, Chen CC. The Association between Harmful Alcohol Use and Internet Addiction among College Students: Comparison of Personality. Psychiatry Clin Neurosci 2009; 63(2):218-24. 
Günüç S, Kayri M. Türkiye’de İnternet Bağımlılık Profili Ve İnternet Bağımlılık Ölçeğinin Geliştirilmesi: Geçerlik ve Güvenirlik Çalışması. Hacettepe Üniversitesi Eğitim Fakültesi Dergisi. 2010. 39: 220-232.

Ko CH, Yen JY, Yen CF, Chen CS, Chen CC. The Association between Internet Addiction and Psychiatric Disorder:A Review of the Literature. European Psychiatry 2012; 27 (1): 1-8.

Cao H, Sun Y, Wan Y, Hao J, Tao F. Problematic Internet Use in Chinese Adolescents and Its Relation to Psychosomatic Symptoms and Life Satisfaction. BMC Public Health 2011; 11: 802 .

Ebeling-Witte S, Frank ML, Lester D. Shyness, Internet Use, and Personality. Cyberpsychol Behav 2007; 10 (5): 713-716.

Bayraktar F. İnternet Kullanımının Ergen Gelişimindeki Rolü. Yayınlanmamış yüksek lisans tezi, İzmir, Ege Üniversitesi, Sosyal Bilimler Enstitüsü, 2001.

Beck AT, Ward CH, Mendelson M, Mock J, Erbaugh J. An İnventory for Measuring Depression. Arch Gen Psychiatry 1961; 4: 561-71.

Hisli N. A Study of the Validity of the Beck Depression Inventory. Turkish J Psychol 1998; 6: 118-22.

Tolonen H, Wolf H., Jakovljevic D, Kuulasmaa K and the European Health Risk Monitoring Project. Review of surveys for risk factors of major chronic diseases and comparability of the results. European Health Risk Monitoring (EHRM) Project. October, 2002. Available at: URL: http://www.ktl.fi/publications/ehrm/product1/title.htm. URN:NBN:fife20021442).

http://www.hiperaktivite.net/hah5_3.htm. available date: 25-04-2012

World Health Organization. Obesity: preventing and managing the global epidemic Report of a WHO consultation on obesity. Technical report series, No 894. Geneva; 2000.

Alaçam H. Denizli Bölgesi Üniversite Öğrencilerinde İnternet Bağımlılığının Görülme Sıklığı ve Yetişkin Dikkat Etkikliği Hiperaktivite Bozukluğu ile İlişkisi, Uzmanlık Tezi, Denizli, Pamukkale Üniversitesi, Sağlık Bilimleri Enstitüsü, 2012.

Canan F, Ataoğlu A, Nichols LA, Yıldırım T, Özturk Ö. Evaluation of Psychometric Properties of the Internet Addiction Scale in a Sample of Turkish High School Students. Cyberpsychol Behav Soc Netw 2010;13(3):317-320.

Willoughby TA. Short- Term Longitudinal Study of Internet and Computer Game Use by Adolescent Boys and Girls: Prevelance, Frequency of Use, and Psychosocial Predictors. Dev Psychol 2008; 44;195-204.

Vaizoğlu SA, Aslan D, Görmüş U, Ünlügüzel G, Özemri S, Akkuş A, Güler C. İnternet Use Amnog High School Students in Ankara, Turkey. Sudi Medical Journal 2004; 25,737-740.

Balcı Ş, Gülnar B. Üniversite Öğrencileri Arasında İnternet Bağımlılı̆̆ı ve İnternet Bağımlılarının Profili. Selçuk İletişim 2009; 6(1): 5-22.

Park SK, Kim JY, Cho CB. Prevalence of Internet Addiction and Correlations with Family Factors among South Korean Adolescents. Adolescence 2008; 43(172): 895-909.

Johansson A, Gotestam K. Internet Addiction: Characteristics of a Questionnaire and Prevalence in Norwegian Youth (12-18 years). Scand J Psychol 2004;45:223-229.

Choi K, Son H, Park M, Han J, Kim K, Lee B, Gwak H. Internet Overuse and Excessive Daytime Sleepiness in Adolescents. Psychiatry Clin Neurosci 2009; 63(4):455-462. 
Üneri ÖŞ, Tanıdır C. Bir Grup Lise Öğrencisinde İnternet Bağımlılı̆ı̆ Değerlendirmesi: Kesitsel Bir Çalışma. Düşünen Adam Psikiyatri ve Nörolojik Bilimler Dergisi 2011; 24:265-272.

Young KS, Rodgers C. The Relationship between Depression and Internet Addiction. Cyberpsychol Behav 1998; 1(1); 25-28.

Kim K, Ryu E, Chon MY, Yeun EJ, Choi SY, Seo JS, Nam BW. Internet Addiction in Korean Adolescents and Its Relation to Depression and Suicidal Ideation: a Questionnaire Survey. Int J Nurs Stud 2006; 43: 185-92.

Yang SC, Tung CJ. Comparison of Internet Addicts and Non-Addicts in Taiwanese High School. Comput Hum Behav 2007; 23, 79-96.

Jang KS, Hwang SY, Choi JY. Internet Addiction and Psychiatric Symptoms Among Korean Adolescents. The Journal of School Health 2008; 78(3):165-71.

Özcan NK, Buzlu S. Problemli İnternet Kullanımını Belirlemede Yardımcı Bir Araç: "İnternette Bilişsel Durum Ölçeği”nin Üniversite Öğrencilerinde Geçerlik ve Güvenirliğii. Bağımlılık Dergisi 2005; 6(1):19-26.

Oğuz B, Zayim N, Özel D, Saka O. Tıp Öğrencilerinin İnternette Bilişsel Durumları. Akademik Bilişim, 2008; 447-453.

Shapira NA, Goldsmith TD, Keck Jr PE, Khosla UM, McElroy SL. Psychiatric Features of Individuals with Problematic Internet Use. J Affect Disord 2000; 57:267-272.

Odabaşıŏlu $\mathrm{G}$ ve ark. İnternet bağımlılığı kaç yaşında başlar?: Sıradışı Bir Vaka Üzerinden Çocuk ve Ergenlerde İnternet Bağımlılı̆̆ı. 3. Ulusal Bağımlılık Kongresi Bilimsel Çalışmalar Kitabı 2006; 56p.

Chou C, Hsiao M C. Internet Addiction, Usage, Gratification, and Pleasure Experience: The Taiwan College Students Case, Comput Educn 2000; 35 (1), 65-80.

Kubey RW, Lavin MJ ve Barrows JR. Internet Use and Collegiate Academic Performance Decrements: Early findings. J Commun 2001; 51, 366-382.

Kandell JJ. Internet Addiction on Campus: the Vulnerability of College Students. Cyberpsychol Behav 1998; 1:11-17.

Anderson KJ. Internet Use among College Students: An Exploratory Study. J Am Coll Health 2001; 50(1); 21-26.

Tsai C, Lin S. Internet Addiction of Adolescents in Taiwan: An Interview Study. Cyberpsychol Behav 2003; 6(6):649-52.

Davis RA. A Cognitive-Behavioral Model of Pathological Internet Use. Comput Human Behav 2001; 17: 187-195.

La Rose R, Eastin MS, Gregg J. Reformulating the Internet Paradox: Social Cognitive Explations of Internet Use and Depression. Journal of Online Behavior 2001; 1(2) http:// www. behavior.net/JOB/v1n1/paradox.html 20.11.2002.

Niemz K, Griffiths M, Banyard P. Prevalence of Patolojical Internet Use among University Students and Correlations with Self-Esteem, the General Health Questionnaire (GHQ), and Disinhibition, Cyberpsychol Behav 2005; 8(6):562-570.

Sanders CE, Field TM, Diego M, ve Kaplan M. The Relationship of Internet Use to Depression and Social Isolation among Adolescents. Adolescence, 2000. 35; 237-241. 